\title{
A Ready-to-Eat Antioxidant Rich Appetizer Based on Coleus aromaticus: Its Development and Shelf Life Evaluation
}

\author{
Pawan Kumar, Dadasaheb Wadikar, and Prakash Patki \\ Defence Food Research Laboratory, DRDO, Siddarthanagar, Mysore, Karnataka 570 011, India \\ Correspondence should be addressed to Dadasaheb Wadikar; ddwadikar@gmail.com
}

Received 24 May 2014; Revised 5 August 2014; Accepted 10 September 2014; Published 8 October 2014

Academic Editor: Vassiliki Oreopoulou

Copyright (C) 2014 Pawan Kumar et al. This is an open access article distributed under the Creative Commons Attribution License, which permits unrestricted use, distribution, and reproduction in any medium, provided the original work is properly cited.

\begin{abstract}
Antioxidant rich products are valued due to their health benefits and appetizers are required in several pathological and geographical stress situations such as prolonged exposure to altitude. The paper deals with the development of a shelf stable RTE (ready-to-eat) antioxidant rich herbal appetizer convenient to the consumer. Using ginger and Karpurvalli (Coleus aromaticus) as two independent variables, a central composite design with 13 experimental combinations was obtained. These combinations were processed by concentration and dehydration into the appetizer RTE munches using preprocessed ingredients and evaluated for antioxidant activity, vitamin C, and sensory characteristics. The product optimized using Design Expert Statistical Software had the proximate composition of $11.4 \%$ fat, $2.3 \%$ protein, and $75.0 \%$ carbohydrates, supplying about $82.36 \mathrm{Kcals}$ per munch of $20 \mathrm{~g}$. The munches packed in metalized polyester pouches had a shelf life of 10 months at $28 \pm 5^{\circ} \mathrm{C}$ as well as $37^{\circ} \mathrm{C}$ storage. The RTE appetizer based on Coleus aromaticus was developed with excellent sensory properties and shelf stability.
\end{abstract}

\section{Introduction}

Coleus aromaticus (CA) commonly called as Country borage or Indian borage is a perennial herb grown throughout Indian subcontinent. Traditionally, the leaves of the plant are used for cold, cough, and fever as well as against skin irritations. The herb has been reported to have several therapeutic potentials. It has been reported that the leaves of the CA herb have antioxidant and radical scavenging activity $[1,2]$, as well as antibacterial and antifungal activities $[3,4]$. The leaves are useful in urinary diseases and vaginal discharge [5]. The expressed juice is used in epilepsy and other convulsive disorders and plant extracts used in the treatment of gastrointestinal disorders [6] while the water extract of CA leaves was found to produce significant diuresis in rats [7]. However, the appetising potential of the herb was unexplored for development of products. Our studies have explored the appetising potential of the CA herb in the form of a shelf stable ready-to-drink beverage called Karpurvalli beverage through animal experiments [8] as well as in a study on human volunteers [9]. A hot water reconstitutable soup mix also has been reported based on the CA herb [10].
Appetite is governed by several factors such as cognizance and memories of the food and psychological and physiological status of the consumer as well as the type of the food and the way the food is being served. The various spices/herbs with pungent volatile compounds cause appetite stimulation through hormonal and metabolic factors. Ginger has been one of the essential ingredients in different appetite influencing foods such as RTE (ready-to-eat) appetizers [11, 12]. The RTE products are highly convenient to carry and to consume for sojourners to altitudes and cold areas. Such products are preferred by soldiers deployed at high altitudes, wherein they can avoid cooking, fuel use, and energy required for preparation of dehydrated mixes. It has been reported [13] that the consumers/sojourners at high altitude gave preference to the preferred sweet taste. The optimization of the product in the present study has been achieved by Statistical Design Software using RSM (Response Surface Methodology). The study aims to provide shelf stable sweet and spicy antioxidant rich appetizer with good acceptability.

\section{Materials and Methods}

2.1. Raw Materials. Karpurvalli (Coleus aromaticus) leaves were obtained from the laboratory's garden-plot specifically 
TABLE 1: Experimental ranges with five levels of independent variables used in CCRD in terms of actual and coded values for Karpurvalli munch.

\begin{tabular}{lcc}
\hline $\begin{array}{l}\text { Variables (range of levels) } \\
\text { Coded value }\end{array}$ & $\begin{array}{c}\text { A: ginger } \\
\text { Actual value }\end{array}$ & $\begin{array}{c}\text { B: Karpurvalli juice } \\
\text { Actual value }\end{array}$ \\
\hline$-\alpha$ & 71.72 & 329.29 \\
-1 & 80 & 350 \\
0 & 100 & 400 \\
+1 & 120 & 450 \\
$+\alpha$ & 128.28 & 470.71 \\
\hline
\end{tabular}

cultivated. Jaggery, ajwain (Trachyspermum ammi) seeds, fresh matured ginger (Zingiber officinalis Roscoe), lemon (Citrus limon), raisins (Vitis vinifera), and ghee (Nandini brand) were procured from the local market. The pectin (HiMedia) and other chemicals and reagents used for analysis were of AR grade.

2.2. Raw Material Processing. The CA leaves were carefully plucked leaving aside the overmature leaves and washed, subjected to juice extraction using a screw type mechanical juice extractor, and filtered through muslin cloth. Jaggery, ajwain, and raisins were cleaned to remove impurities prior to further use. The raisins were fried in ghee at $160-180^{\circ} \mathrm{C}$ for 30-50 seconds and cooled thoroughly and were ground. Ginger (fresh) was washed in lukewarm $\left(40-50^{\circ} \mathrm{C}\right)$ water, cleaned, peeled, and cut into pieces and then was ground into a paste using warring blender. Lemons (mature fruits) were washed in hot water and halved with knife and juice was extracted using squeezers and filtered. Ajwain seeds were cleaned and finely ground to pass through 60-mesh sieve.

2.3. Experimental Design. A five-level central composite rotatable design was constructed with two independent variables. The Design Expert version 8.0 Statistical Software package from Stat ease Inc., USA, was used to construct and to analyze the design. Karpurvalli juice and ginger paste were taken as independent variable with sensory score vitamin C and antioxidant activity as the responses. The experimental design with two variables had 13 design points including five centre point replications. The range of independent variables studied with coded and actual values are given in Table 1. The $\alpha$-values in the design outside the ranges were selected for rotatability of the design [14]. The center points were selected with ingredients at levels expected to yield satisfactory experimental results. The regression analysis of the responses was conducted by fitting suitable either linear or quadratic model.

2.4. Appetizer Processing. The Karpurvalli juice and ginger paste were weighed as per the design to form different formulation batches, while other ingredients such as lemon juice, jaggery, raisins, ajwain powder, and pectin were at fixed levels. Dissolved and filtered jaggery solution was taken in a LPG based open top concentrator (M/s. Solar arks, Kolhapur, India) and other ingredients were added one by one with continued stirring. The appetizer was prepared by concentration and dehydration technique with continuous stirring while heating at $160-200^{\circ} \mathrm{C}$. The end point determination was a critical point identified when the concentrating semisolid mass begins leaving the pan surface and product exhibiting characteristic gloss. In hot condition, the product was poured into trays precoated with ghee. After cooling, $20 \mathrm{~g}$ samples were weighed and hand-moulded into oval shapes as individual munches and then packed in metalized polyester pouches and stored at ambient conditions $18-33^{\circ} \mathrm{C}$ and $37^{\circ} \mathrm{C}$.

2.5. Analytical Evaluation. The proximate analysis which includes crude protein, fat, ash, and moisture content of Karpurvalli munch was carried out by standard AOAC procedures [15]. The acidity as citric acid and vitamin $C$ were determined by titrimetry [16]. Changes in the thiobarbituric acid (TBA) value during storage were estimated by steam distillation method wherein the distillate was treated with TBA solution and OD was measured at $540 \mathrm{~nm}$ [17]. For estimation of sugars the sample was made protein free using lead acetate and potassium oxalate. The estimation of reducing and total sugars was done [15] using Fehling A and Fehling $\mathrm{B}$ solution and titration. The antioxidant activity based on 1,1-diphenyl-2-picrylhydrazyl free radical-scavenging activity was measured by the method reported by Braca et al. [18]. The sample $(2 \pm 0.01 \mathrm{~g})$ preparation was done using methanolic solution (water: methanol, 1:2). The absorbance was measured at $517 \mathrm{~nm}$ using UV spectrophotometer (Model-UV2550 from M/s. Shimadzu Corporation, Japan) and expressed as \% scavenging activity. Total phenols estimation was carried out with Folin-Ciocalteu reagent (FCR) [19] wherein the sample $0.5-1 \pm 0.01 \mathrm{~g}$ was weighed and ground with 10 times of $80 \%$ methanol in a pestle mortar. The homogenate was centrifuged at 10,000 rpm for $20 \mathrm{~min}$ and the supernatant was saved. The procedure was repeated again with 5 volumes of ethanol and the supernatant was pooled and evaporated at a low temperature. The residue was dissolved in $5 \mathrm{~mL}$ distilled water and $0.2-2 \mathrm{~mL}$ aliquots were pipetted in the test tubes. The final volume was made up to $3 \mathrm{~mL}$, followed by $0.5 \mathrm{~mL}$ diluted FCR. After $3 \mathrm{~min}, 2 \mathrm{~mL} 7 \%$ sodium carbonate was added and the mixture was placed in a boiling water bath for $2 \mathrm{~min}$. The tubes were cooled and absorbance was measured at $750 \mathrm{~nm}$, against blank.

For estimation of dietary fibre [20], sample (1 g) was taken in Erlenmeyer flask, $25 \mathrm{~mL}$ of $0.1 \mathrm{M}$ sodium phosphate buffer ( $\mathrm{pH}$ 6.0) added to suspended uniformly. $100 \mathrm{mg}$ of Termamyl was added and incubated in a boiling water bath for $15 \mathrm{~min}$ and cooled and $20 \mathrm{~mL}$ of distilled water was added and $\mathrm{pH}$ was adjusted to 1.5 with $4 \mathrm{~N} \mathrm{HCl}$ (hydrochloric acid). $100 \mathrm{mg}$ of pepsin was added and incubated at $40^{\circ} \mathrm{C}$ with agitation for $60 \mathrm{~min}$ and cooled and $20 \mathrm{~mL}$ of water was added and $\mathrm{pH}$ was adjusted to 6.8 with $4 \mathrm{~N}$ sodium hydroxide. $100 \mathrm{mg}$ of pancreatin enzyme was added and incubated at $40^{\circ} \mathrm{C}$ with agitation for $60 \mathrm{~min}$ and cooled and $\mathrm{pH}$ was adjusted to 4.5 
TABLE 2: Central composite rotatable design of experiments for Karpurvalli munch.

\begin{tabular}{|c|c|c|c|c|c|c|}
\hline Std. order & Run order & $\begin{array}{c}\text { Factor } 1 \\
\text { ginger }(\mathrm{g})\end{array}$ & $\begin{array}{c}\text { Factor } 2 \\
\text { Karpurvalli juice (g) }\end{array}$ & $\begin{array}{c}\text { Response } 1 \\
\text { antioxidant activity (\%) }\end{array}$ & $\begin{array}{c}\text { Response } 2 \\
\text { vitamin C (mg/100 g) }\end{array}$ & $\begin{array}{r}\text { Response } 3 \\
\text { sensory score }\end{array}$ \\
\hline 6 & 1 & 128.28 & 400.00 & 76.63 & 10.81 & 7.63 \\
\hline 8 & 2 & 100.00 & 470.71 & 79.52 & 12.18 & 7.06 \\
\hline 9 & 3 & 100.00 & 400.00 & 74.52 & 10.80 & 7.13 \\
\hline 13 & 4 & 100.00 & 400.00 & 85.66 & 10.82 & 6.76 \\
\hline 1 & 5 & 80.00 & 350.00 & 75.85 & 10.93 & 6.71 \\
\hline 3 & 6 & 80.00 & 450.00 & 85.50 & 10.82 & 7.23 \\
\hline 7 & 7 & 100.00 & 329.29 & 84.24 & 10.26 & 7.7 \\
\hline 5 & 8 & 71.72 & 400.00 & 85.36 & 11.89 & 7.13 \\
\hline 2 & 9 & 120.00 & 350.00 & 76.57 & 10.80 & 7.23 \\
\hline 10 & 10 & 100.00 & 400.00 & 82.43 & 11.88 & 7.3 \\
\hline 4 & 11 & 120.00 & 450.00 & 84.73 & 12.44 & 7.35 \\
\hline 11 & 12 & 100.00 & 400.00 & 88.01 & 11.88 & 7.47 \\
\hline 12 & 13 & 100.00 & 400.00 & 82.90 & 11.34 & 7.43 \\
\hline
\end{tabular}

with $4 \mathrm{~N} \mathrm{HCl}$. The treated sample was then filtered through the dry Celite as the filter aid.

Insoluble Fibre. The residue was washed with $2 \times 10 \mathrm{~mL}$ of $95 \%$ alcohol and acetone, dried at $105 \pm 2^{\circ} \mathrm{C}$ to constant weight, and weight of the crucibles was noted $\left(D_{1}\right)$ and incinerated at $550^{\circ} \mathrm{C}$ for $5 \mathrm{~h}$. After cooling, weight of the crucibles was noted $\left(I_{1}\right)$.

Soluble Fibre. The volume of the filtrate was made up to $100 \mathrm{~mL}, 400 \mathrm{~mL}$ of warm $95 \%$ alcohol was added, kept for $1 \mathrm{~h}$ to precipitate, then filtered through the dried and weighed crucible $\left(D_{2}\right)$, and washed with $2 \times 10 \mathrm{~mL}$ of alcohol and acetone and dried at $105 \pm 2^{\circ} \mathrm{C}$ overnight. Incinerated at $550 \pm 10^{\circ} \mathrm{C}$ for $5 \mathrm{~h}$, cooled and weighed the crucibles $\left(I_{2}\right)$.

Blank (B). Insoluble and soluble blanks were also run without sample following the same procedure:

$$
\begin{aligned}
& \text { Insoluble dietary fibre }(\%)=\frac{D_{1}-I_{1}-B}{W} \times 100 \\
& \text { Soluble dietary fibre }(\%)=\frac{D_{2}-I_{2}-B}{W} \times 100
\end{aligned}
$$

where $W$ = weight of the sample.

2.6. Sensory Evaluation. All the combinations of the Karpurvalli munch were evaluated for their sensory attributes on 9-point hedonic scale by semitrained panel of 15 members during product development as well as storage study. The 9point Hedonic scale grading was gradual from $9=$ excellent to $1=$ extremely poor. The statistical analysis for significance was carried out using trial version of SPSS 19 software.

\section{Results and Discussion}

Response surface designs have been proven to be quite useful in product and process optimisation. The responses used in the design for a development of products have sensory quality as one of the default response. Several researchers have studied sensory score along with other responses such as texture [21], acidity, total carotenoids, total sugars [10,11], antioxidant activity, vitamin C [22], cutting force, and acidity [12] as one of the most important parameter of product development. Similarly in optimisation of the Karpurvalli munch developed in the present study, sensory score was one of the responses. As the product contains CA herb and ginger as crucial ingredients apart from other ingredients such as lemon juice and raisins, the antioxidant activity and vitamin $\mathrm{C}$ were taken as other responses in the study. The experimental design with actual levels of independent variables and the responses used in this study are given in Table 2. The observation recorded at different design points revealed that the \% antioxidant activity ranged from 74.52 to 88.01 , the vitamin $C$ content from 10.26 to $12.44 \mathrm{mg} / 100 \mathrm{~g}$, and the sensory score from 6.71 to 7.63. These responses were then subjected to model fitting by studying the ANOVA values and using the diagnostics tool available in the Design Expert Software. The ANOVA and the best fit polynomial models were obtained for all the three responses (Table 3), to assess how well the model represented the data. The quadratic model was fit for the antioxidant activity response with high model $F$-value of 50.97 while for the other two responses linear model was found suitable with nonsignificant lack of fit. The antioxidant activity was influenced by interaction among the ingredients used in product formulation; however, it was mainly increased with the level of Karpurvalli juice, while the ginger juice has opposite effect (Figure 1). The vitamin $\mathrm{C}$ was not affected much by the level of ginger, while the Karpurvalli juice had significant effect (Figure 2). The 
TABLE 3: ANOVA and model statistics of the Karpurvalli munch.

\begin{tabular}{lcccc}
\hline \multirow{2}{*}{ Sl number } & \multirow{2}{*}{ Term } & \multicolumn{3}{c}{ Response } \\
& & $\begin{array}{c}\text { Antioxidant } \\
\text { activity }\end{array}$ & $\begin{array}{c}\text { Vitamin } \\
\text { C }\end{array}$ & $\begin{array}{c}\text { Sensory } \\
\text { score }\end{array}$ \\
\hline 1 & Model & Quadratic & Linear & Linear \\
2 & $F$-value & 50.97 & 8.48 & 19.44 \\
3 & $P>F$ & $<0.0001$ & 0.0007 & 0.0004 \\
4 & Mean & 81.57 & 11.41 & 7.29 \\
5 & S.D. & 0.88 & 0.43 & 0.15 \\
6 & CV\% & 1.08 & 3.79 & 2.03 \\
7 & $R$ squared & 0.9733 & 0.6290 & 0.7955 \\
8 & Adjusted $R$ squared & 0.9542 & 0.5547 & 0.7545 \\
9 & Predicted $R$ squared & 0.8556 & 0.4206 & 0.6463 \\
10 & Adequate precision & 21.673 & 7.951 & 12.429 \\
\hline
\end{tabular}

*Standard deviation.

sensory score was affected by both ingredients (Figure 3), but the effect was more prominent with changes in levels of ginger. The regression equation obtained for the three responses are as follows:

$$
\begin{aligned}
\text { Antioxidant Acitivity }= & +83.31-2.82 \mathrm{~A}+3.68 \mathrm{~B} \\
& +0.69 \mathrm{AB}-1.32 \mathrm{~A}^{2}-1.51 \mathrm{~B}^{2} \\
\text { Vitamin } \mathrm{C}=+ & +11.41-0.23 \mathrm{~A}+0.58 \mathrm{~B} \\
\text { Sensory score }= & +7.29+0.29 \mathrm{~A}-0.15 \mathrm{~B} .
\end{aligned}
$$

The numerical optimisation approach of Design Expert was used to get the solution with criteria to maximize all the three responses. The optimized ingredient levels with the predicted responses are given in Figure 4. The product was prepared with the optimised ingredient levels and was evaluated for the responses to validate the prediction strength of the models used in the present study. The actual observed sensory score of the optimised product was $7.4 \pm 0.12$ while the antioxidant activity and vitamin C content were $81.14 \%$ and $11.77 \mathrm{mg} / 100 \mathrm{~g}$. The predicted (Figure 4) and actual response values were in close concurrence with each other validating the robustness of the models. Thus, the final ingredient composition of the optimised Karpurvalli munch included Karpurvalli juice $42.6 \%$, jaggery $26.5 \%$, raisins $13.2 \%$, ginger paste $11.3 \%$, ghee $3.60 \%$, and lemon juice $2.8 \%$. In addition to these small quantities of ajwain powder and pectin were added to improve the flavour and texture of the product, respectively, during all the preparations.

The chemical composition of the optimised Karpurvalli munch (Table 4) revealed that the product is a good source of antioxidants and vitamin $\mathrm{C}$ with about $82.4 \mathrm{Kcal}$ per munch of $20 \mathrm{~g}$. It also has good amount of reducing sugars and dietary fibre as well. Similar appetiser munches with calorific value of 76-90 Kcal per munch of $20 \mathrm{~g}$ have been reported $[11,12]$. The vitamin C content was of $37-43 \mathrm{mg} / 100 \mathrm{~g}$ in ginger based RTE appetisers; however, in the present context it is $11.77 \mathrm{mg} / 100 \mathrm{~g}$ of product. Antioxidant activity of foods has gained nutritional importance due to the potential
TABLE 4: Chemical analysis of optimised Karpurvalli munch.

\begin{tabular}{lc}
\hline Parameter & Value \\
\hline Moisture & $4.94 \%$ \\
Protein & $2.30 \%$ \\
Fat & $11.04 \%$ \\
Sugar & \\
$\quad$ (a) Total sugar & $59.25 \%$ \\
$\quad$ (b) Reducing sugar & $37.98 \%$ \\
Ash & \\
$\quad$ (a) Total ash & $2.90 \%$ \\
$\quad$ (b) Acid insoluble & $0.31 \%$ \\
Dietary fibre & \\
$\quad$ (a) Total dietary fibre & $4.13 \%$ \\
$\quad$ (b) Insoluble dietary fibre & $1.13 \%$ \\
Vitamin C & $11.77 \mathrm{mg} / 100 \mathrm{~g}$ \\
Antioxidant activity (DPPH free radical & $81.14 \%$ \\
scavenging) & \\
TBA value & $0.07 \mathrm{mg} / \mathrm{Kg}$ \\
Total phenols & $15.2 \mathrm{~g} / 100 \mathrm{~g}$ \\
\hline
\end{tabular}

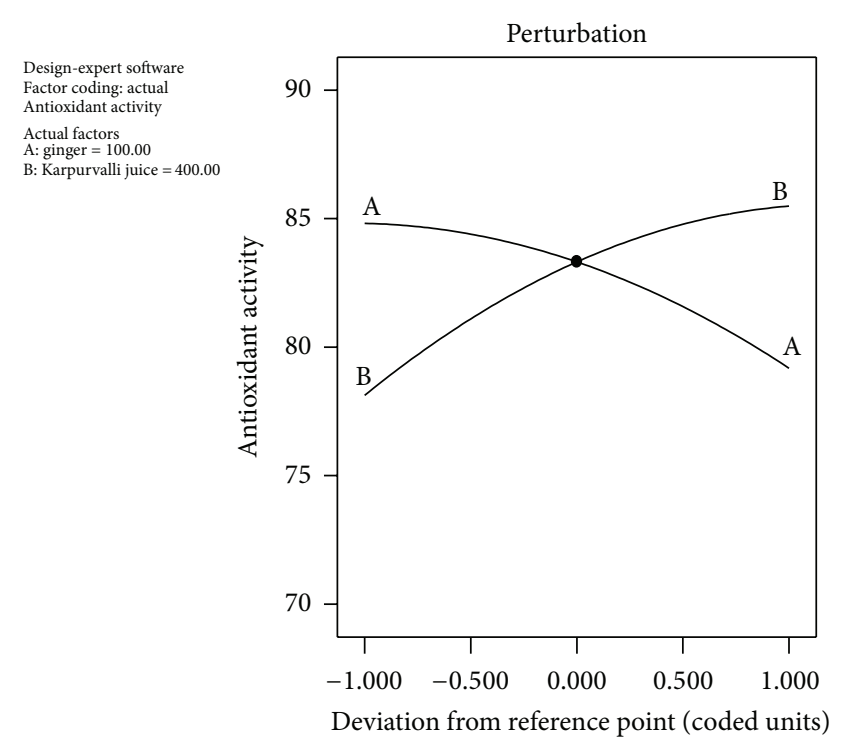

FIGURE 1: Effetct of different levels of variable on antioxidant acitivity of the product.

protective effect on health. Kovačević et al. [23] reported that compared to fresh strawberry fruit, whose antioxidant activity was in the range of $90.74 \%$ to $92.41 \%$, the jams also represent a noticeable source of antioxidant compounds, with the antioxidant activity of $83.76 \%$ to $85.65 \%$. Another report [24] on low sugar bilberry jam states that the thermal processing resulted in decrease of ascorbic acid content, total phenolics, and ferric reducing antioxidant powers which further decrease during storage. However, in the present context the antioxidant activity is not dependent on one principal ingredient and is collectively contributed by CA 


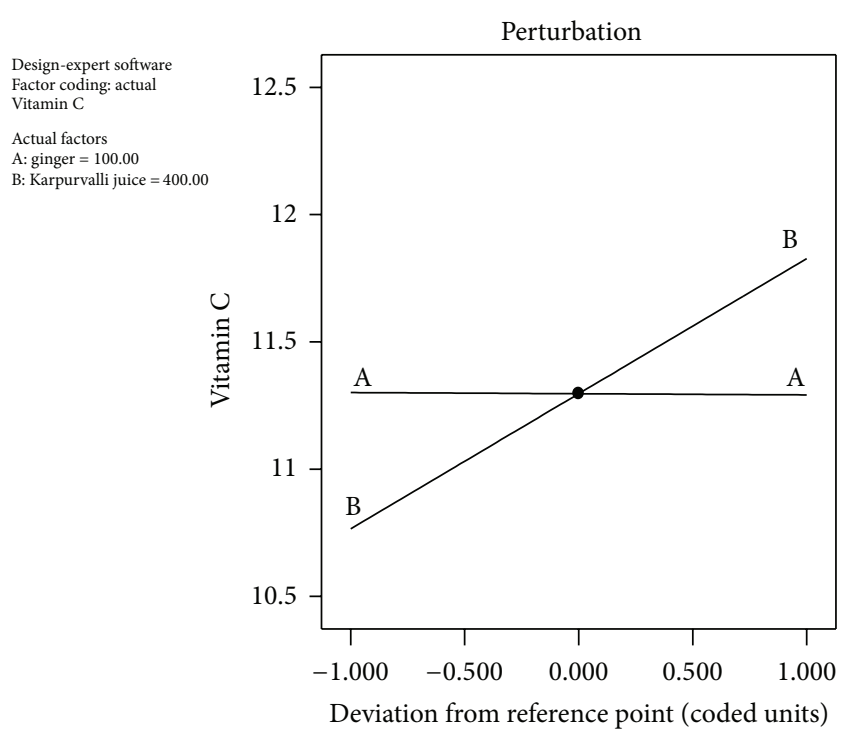

FIGURE 2: Effetct of different levels of variable on vitamin $\mathrm{C}$ of the product.

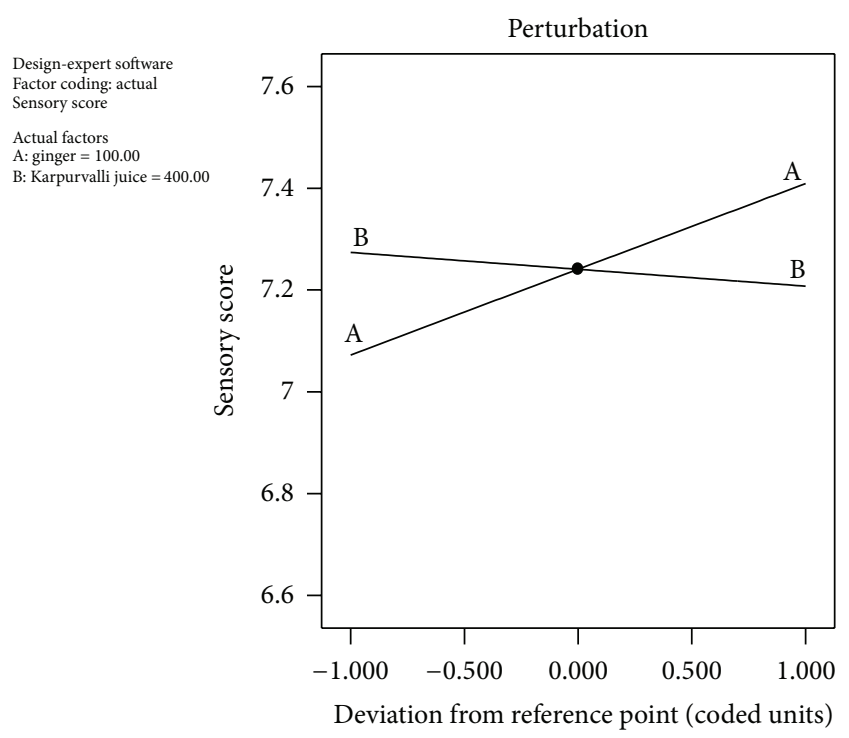

FIGURE 3: Effetct of different levels of variable on sensory score of the product.

leaves, ginger, and lemon juice. The antioxidant activity in the optimised Karpurvalli munch was found to be $81 \pm 0.5 \%$.

The shelf stability of the product was studied in laminated pouches. Periodic evaluation of the sensory attributes and quality parameters such as TBA value, vitamin C, and antioxidant activity revealed (Table 5) that the Karpurvalli munch underwent slow and gradual deteriorative changes. The sensory scores gradually decreased during storage; however, the magnitude of reduction was more in samples stored at $37^{\circ} \mathrm{C}$. The sensory score differed among samples stored at $5^{\circ} \mathrm{C}$ and RT after the 6 months of storage while the samples stored at $37^{\circ} \mathrm{C}$ the reduction was statistically significant $(P<0.05)$ after 4 months of storage. The TBA value which measures
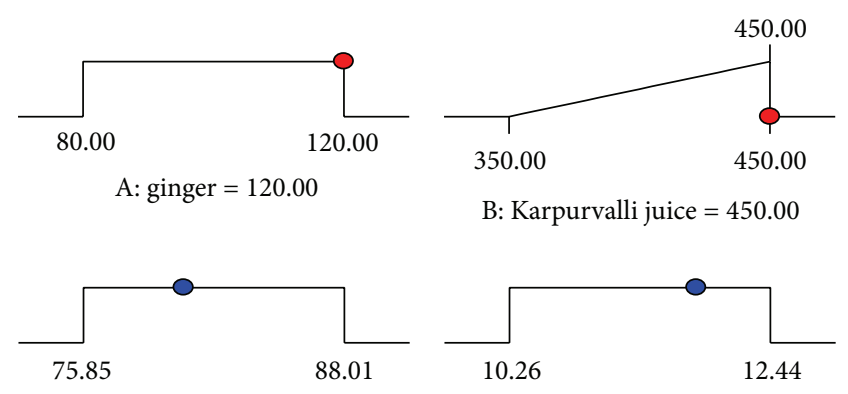

Antioxidant activity $=80.5199$

B: Karpurvalli juice $=450.00$

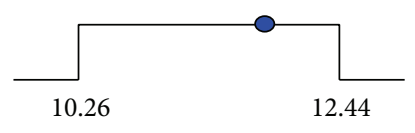

Vitamin $\mathrm{C}=11.8221$

Desirability $=0.781$

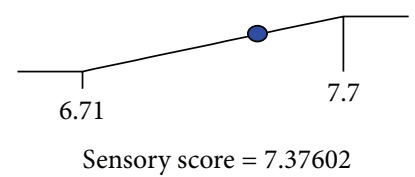

FIGURE 4: Optimised ingredient level and the predicted response values.

the lipid spoilage rendering rancidity and off-flavour to the product was low and did not show accelerated increase in it. Though after 10 months of storage at $\mathrm{RT}$ and $37^{\circ} \mathrm{C}$ it increased up to 0.4 and $0.6 \mathrm{mg}$ malonaldehyde/ $\mathrm{kg}$, respectively; the product was acceptable for its sensory attributes. The retarded pace of oxidative deterioration may be attributed to inbuilt antioxidant activity in the product. The TBA values of the Karpurvalli munch differed significantly $(P<0.05)$ among the storage conditions of refrigerated storage and at room temperature as well as $37^{\circ} \mathrm{C}$ throughout the periodic evaluation. The vitamin $\mathrm{C}$ and antioxidant activity were reduced by more than $70 \%$ after 10 -month storage at $\mathrm{RT}$ and $37^{\circ} \mathrm{C}$; however, it was retained by more than $50 \%$ for samples stored at refrigerated conditions. There was significant difference in retention of vitamin $\mathrm{C}$ and antioxidant activity among the different storage temperatures. Thus the product was found stable for more than 10 months at ambient conditions.

A similar trend of storage change but in different product with different intensity was reported [25] wherein the antioxidant capacity in terms of \% DPPH free radical scavenging ability and vitamin $\mathrm{C}$ was found to reduce during storage at different temperature conditions over a period of six months in case of certain orange juices. Burdurlu et al. [26] reported reductions in vitamin $\mathrm{C}$ content of citrus juice concentrates during storage. They reported that the ascorbic acid retention after storage at 28,37 , and $45^{\circ} \mathrm{C}$ was about $54.5-$ $83.7 \%, 23.6-27 \%$, and $15.1-20.0 \%$, respectively. The gradual increase in TBA value during storage of similar products over the storage period of 8 months has been reported [11] wherein the TBA values were found to increase up to 0.7$0.9 \mathrm{mg}$ malonaldehyde $/ \mathrm{kg}$ with sensory scores going below 6.5 without any objectionable flavours. In case of an instant sweet mix based on soybean and semolina, increase in TBA values and a gradual decrease in sensory attributes had been reported [27] over the storage period of 6 months in PP pouches in ambient conditions. In another report [28] on 
TABle 5: Parameters studied for establishing shelf life of Karpurvalli munch $(n=2)$.

\begin{tabular}{|c|c|c|c|c|c|}
\hline Storage temp. & Storage period (months) & Sensory score ${ }^{* \#}$ & Vitamin C (mg/100 gm) & TBA value (mg/kg) & Antioxidant activity (\%) \\
\hline \multirow{6}{*}{$5^{\circ} \mathrm{C}$} & 0 & $8.02 \pm 0.2^{\mathrm{a}}$ & 11.77 & 0.070 & 82.14 \\
\hline & 2 & $7.80 \pm 0.3^{\mathrm{a}}$ & 11.55 & 0.082 & 79.45 \\
\hline & 4 & $7.60 \pm 0.5^{\mathrm{a}}$ & 10.92 & 0.097 & 71.23 \\
\hline & 6 & $7.52 \pm 0.2^{\mathrm{a}}$ & 9.38 & 0.123 & 67.89 \\
\hline & 8 & $7.46 \pm 0.4^{\mathrm{a}}$ & 8.14 & 0.148 & 62.15 \\
\hline & 10 & $7.32 \pm 0.3^{\mathrm{a}}$ & 6.79 & 0.179 & 51.82 \\
\hline \multirow{6}{*}{$\begin{array}{l}\mathrm{RT} \\
\left(28 \pm 5^{\circ} \mathrm{C}\right)\end{array}$} & 0 & $8.02 \pm 0.2^{\mathrm{a}}$ & 11.77 & 0.070 & 82.14 \\
\hline & 2 & $7.80 \pm 0.5^{\mathrm{a}}$ & 11.28 & 0.191 & 77 \\
\hline & 4 & $7.56 \pm 0.3^{\mathrm{a}}$ & 10.17 & 0.236 & 60.17 \\
\hline & 6 & $7.41 \pm 0.2^{\mathrm{b}}$ & 8.13 & 0.261 & 51.30 \\
\hline & 8 & $7.30 \pm 0.3^{\mathrm{b}}$ & 6.51 & 0.307 & 40.79 \\
\hline & 10 & $7.08 \pm 0.2^{\mathrm{b}}$ & 4.78 & 0.412 & 29.83 \\
\hline \multirow{6}{*}{$37^{\circ} \mathrm{C}$} & 0 & $8.02 \pm 0.2^{\mathrm{a}}$ & 11.77 & 0.070 & 82.14 \\
\hline & 2 & $7.70 \pm 0.3^{\mathrm{a}}$ & 11.27 & 0.269 & 75.05 \\
\hline & 4 & $7.32 \pm 0.2^{\mathrm{b}}$ & 8.76 & 0.356 & 51.48 \\
\hline & 6 & $7.18 \pm 0.3^{\mathrm{bc}}$ & 5.41 & 0.401 & 43.58 \\
\hline & 8 & $7.01 \pm 0.4^{\mathrm{bc}}$ & 3.19 & 0.473 & 31.72 \\
\hline & 10 & $6.60 \pm 0.4^{b c}$ & 2.30 & 0.609 & 19.98 \\
\hline
\end{tabular}

RT: room temperature; ${ }^{*}$ score on nine-point Hedonic scale ( $n=15$ panelists).

${ }^{\#}$ Different alphabet superscripts in the same column indicate statically significant difference.

two RTE appetizer munches, the acceptability of the products was very good initially with a sensory score of 3.8 and 3.4 on 5-point hedonic scale for pepper munch and lemon munch which reduced to 2.7 and 2.9 after 9 months of storage, while the TBA value increased from 0.05 and 0.02 to 0.28 and $0.3 \mathrm{mg}$ malonaldehyde $/ \mathrm{kg}$, respectively for the two appetizers. In another study, a shelf life of a similar ready to eat appetiser based on Trachyspermum ammi has been reported [12] wherein the acidity, TBA value, and sensory cores were monitored. The initial values of sensory score was reduced from 8.6 to 7.2 and 6.5 , acidity was increased from $0.48 \%$ to 0.83 and $0.89 \%$, while the TBA value increased from 0.03 to $0.2-0.28 \mathrm{mg}$ malonaldehyde $/ \mathrm{kg}$ at RT and $37^{\circ} \mathrm{C}$, respectively, over the storage period.

These studies indicated that it is a trend in similar products during storage and the results obtained in the present context are comparable to the other reports on such products.

\section{Conclusion}

It can be concluded that a shelf stable antioxidant rich appetising product was prepared using the herb Coleus aromatics. The herb has been successfully explored for its use in an RTE product never reported earlier. The product has a shelf life of 10 months at ambient conditions when stored in sealed metalized polyester pouches.

\section{Conflict of Interests}

The authors report no conflict of interests.

\section{Acknowledgment}

The authors acknowledge the support and encouragement given by The Director, DFRL, Mysore, for carrying out the work. The authors alone are responsible for the content and writing of the paper.

\section{References}

[1] B. S. S. Rao, R. Shanbhoge, D. Upadhya et al., "Antioxidant, anticlastogenic and radioprotective effect of Coleus aromaticus on Chinese hamster fibroblast cells (V79) exposed to gamma radiation," Mutagenesis, vol. 21, no. 4, pp. 237-242, 2006.

[2] A. Kumaran and R. Joel Karunakaran, "Antioxidant and free radical scavenging activity of an aqueous extract of Coleus aromaticus," Food Chemistry, vol. 97, no. 1, pp. 109-114, 2006.

[3] R. A. Pritima and R. S. Pandian, "Antimicrobial activity of Coleus aromaticus (benth) against microbes of reproductive tract infections among women," African Journal of Infectious Diseases, vol. 1, pp. 18-24, 2007.

[4] A. Revathi, B. Thangabalan, P. Vengal Rao, and K. Vadivel, "Microbiological activity of essential oil extracted from Coleus aromaticus Linn. leaves," Research Journal of Pharmaceutical, Biological and Chemical Sciences, vol. 2, no. 1, pp. 12-14, 2011.

[5] B. R. Shamachar, "Use of "Pashanabheda" Coleus aromaticus in ashmari (urinary calculi)," National Medical Journal, vol. 9, no. 3, pp. 475-477, 1967.

[6] A. Chatterjee, The Treatise on Indian Medicinal Plants, vol. 5, National Institute of Science Communication, New Delhi, India, 1997.

[7] T. K. Sur, S. Pandit, T. K. Biswas, R. B. Ghosh, and D. Bhattacharyya, "Diuretic activity of Coleus aromaticus Benth on rats," Ancient Science of Life, vol. 22, no. 4, pp. 1-4, 2003. 
[8] D. D. Wadikar and K. S. Premavalli, "Appetizer administration stimulates food consumption, weight gain and leptin levels in male Wistar rats," Appetite, vol. 57, no. 1, pp. 131-133, 2011.

[9] D. D. Wadikar and K. S. Premavalli, "Beverage from Coleus aromaticus reduces leptin levels and improves appetite rating in human volunteers," Nutrition, vol. 30, no. 6, pp. 702-705, 2014.

[10] D. D. Wadikar and K. S. Premavalli, "Development of a hot water reconstitutable appetizer soup mix from Coleus aromaticus using response surface methodology," International Food Research Journal, vol. 20, no. 6, pp. 3041-3046, 2013.

[11] D. D. Wadikar, C. Nanjappa, K. S. Premavalli, and A. S. Bawa, "Development of ginger based ready-to-eat appetizers by response surface methodology," Appetite, vol. 55, no. 1, pp. 7683, 2010.

[12] D. D. Wadikar and K. S. Premavalli, "Ajowan (Trachyspermum ammi) munch: a shelf stable ready-to-eat appetizer, its development and storage," International Food Research Journal, vol. 19, no. 1, pp. 321-325, 2012.

[13] S. B. Singh, A. Sharma, D. K. Yadav et al., "High altitude effects on human taste intensity and hedonics," Aviation Space and Environmental Medicine, vol. 68, no. 12, pp. 1123-1128, 1997.

[14] D. Thompson, "Response surface experimentation," Journal of Food Processing and Preservation, vol. 6, no. 3, pp. 155-188, 1982.

[15] AOAC, Official Methods of Analysis, Association of Official Analytical Chemists, Washington, DC, USA, 12th edition, 1975.

[16] S. Ranganna, Hand Book of Analysis and Quality Control for Fruit and Vegetable Products, Tata McGraw-Hill, New Delhi, India, 1986.

[17] B. G. Tarladgis, B. M. Watts, M. T. Younathan, and L. Dugan Jr., "A distillation method for the quantitative determination of malonaldehyde in rancid foods," Journal of the American Oil Chemists Society, vol. 37, no. 1, pp. 44-48, 1960.

[18] A. Braca, N. De Tommasi, L. Di Bari, C. Pizza, M. Politi, and I. Morelli, "Antioxidant principles from Bauhinia tarapotensis," Journal of Natural Products, vol. 64, no. 7, pp. 892-895, 2001.

[19] S. R. Thimmaiah, "Phenolics: estimation of total phenols," in Standard Methods of Biochemical Analysis, pp. 287-288, Kalyani, Guwahati, India, 2006.

[20] N.-G. Asp, C.-G. Johansson, H. Hallmer, and M. Siljeström, "Rapid enzymatic assay of insoluble and soluble dietary fiber," Journal of Agricultural and Food Chemistry, vol. 31, no. 3, pp. 476-482, 1983.

[21] S. Singh, C. S. Raina, A. S. Bawa, and D. C. Saxena, "Sweet potato-based pasta product: optimization of ingredient levels using response surface methodology," International Journal of Food Science \& Technology, vol. 39, no. 2, pp. 191-200, 2004.

[22] C. S. Devaki and K. S. Premavalli, "Development of bittergourd fermented beverage using response surface methodology," Journal of Pharmacy and Nutrition Sciences, vol. 2, no. 1, pp. 94-103, 2012.

[23] D. B. Kovačević, L. Branka, and D.-U. Verica, "Free radical scavenging activity and phenolic content in strawberry fruit and jam," Agriculturae Conspectus Scientificus, vol. 74, no. 3, pp. 155159, 2009.

[24] M.-A. Poiana, E. Alexa, and C. Mateescu, "Tracking antioxidant properties and color changes in low-sugar bilberry jam as effect of processing, storage and pectin concentration," Chemistry Central Journal, vol. 6, article 4, 2012.

[25] I. Klimczak, M. Małecka, M. Szlachta, and A. GliszczyńskaŚwigło, "Effect of storage on the content of polyphenols, vitamin $\mathrm{C}$ and the antioxidant activity of orange juices," Journal of Food Composition and Analysis, vol. 20, no. 3-4, pp. 313-322, 2007.
[26] H. S. Burdurlu, N. Koca, and F. Karadeniz, "Degradation of vitamin $\mathrm{C}$ in citrus juice concentrates during storage," Journal of Food Engineering, vol. 74, no. 2, pp. 211-216, 2006.

[27] D. N. Yadav, G. K. Sharma, and A. S. Bawa, "Optimization of soy-fortified instant sooji halwa mix using response surface methodology," Journal of Food Science and Technology, vol. 44, no. 3, pp. 297-300, 2007.

[28] D. D. Wadikar, C. Nanjappa, K. S. Premavalli, and A. S. Bawa, "Development of ready-to-eat appetisers based on pepper and their quality evaluation," Journal of Food Science \& Technology, vol. 47, no. 6, pp. 638-643, 2010. 

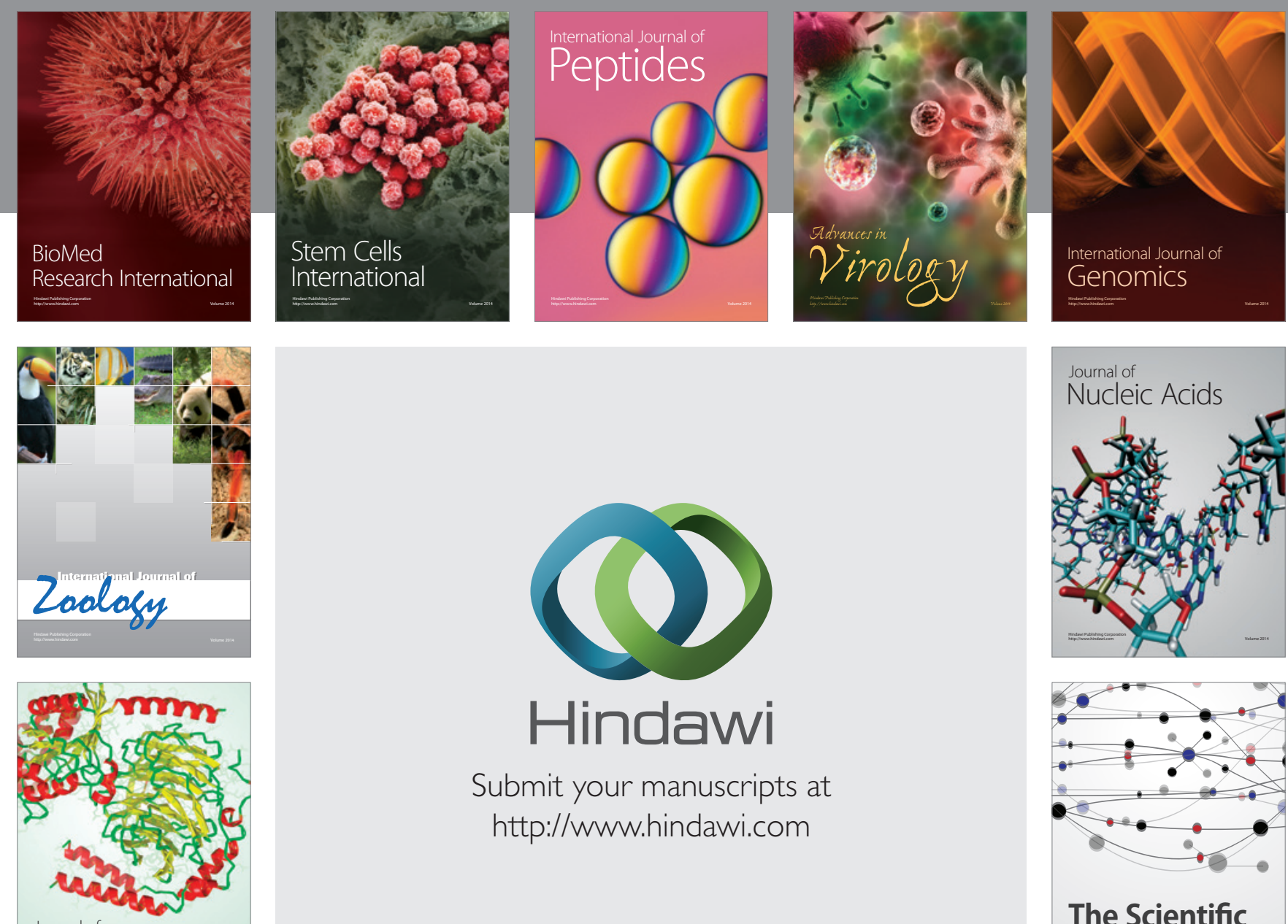

Submit your manuscripts at

http://www.hindawi.com

Journal of
Signal Transduction
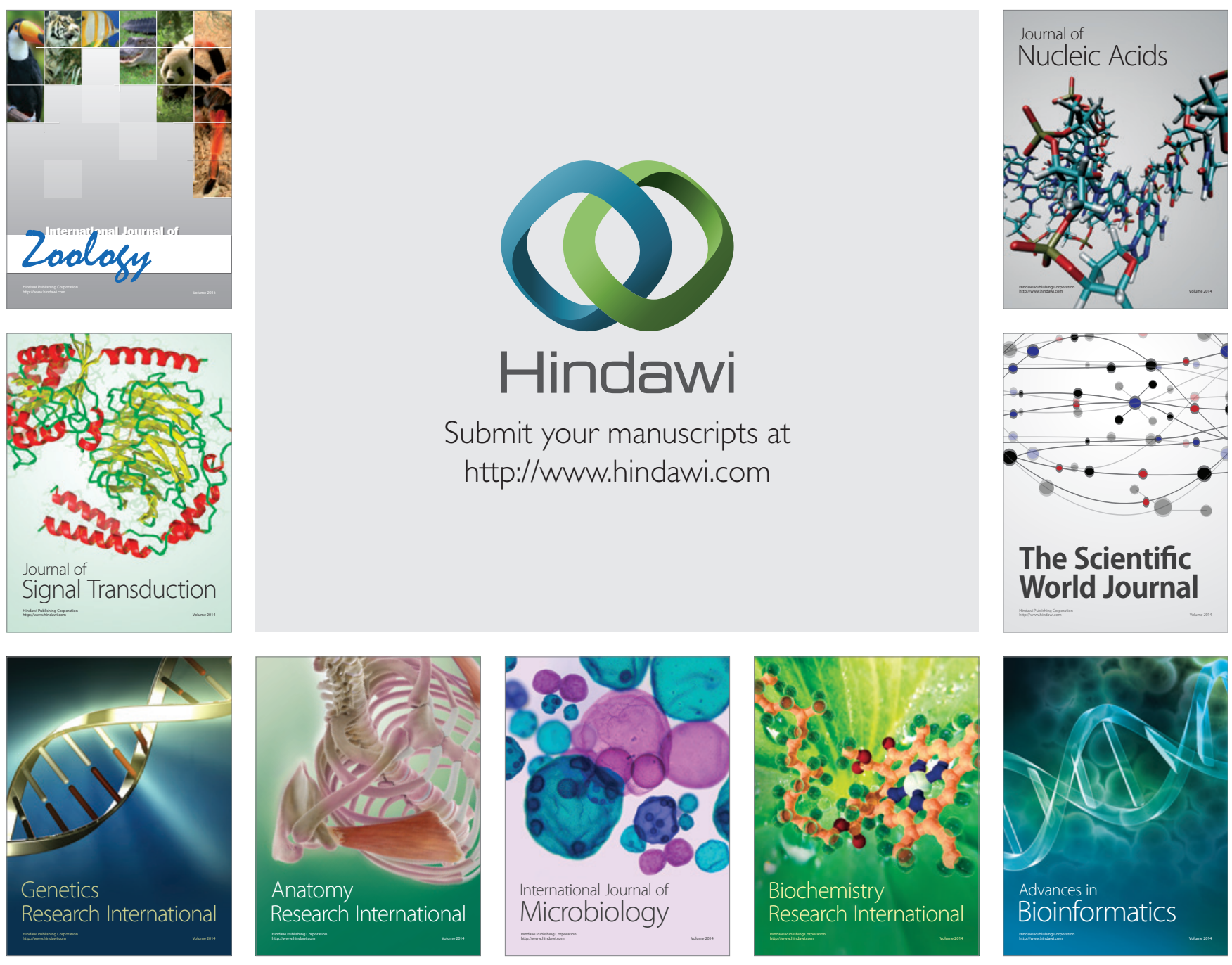

The Scientific World Journal
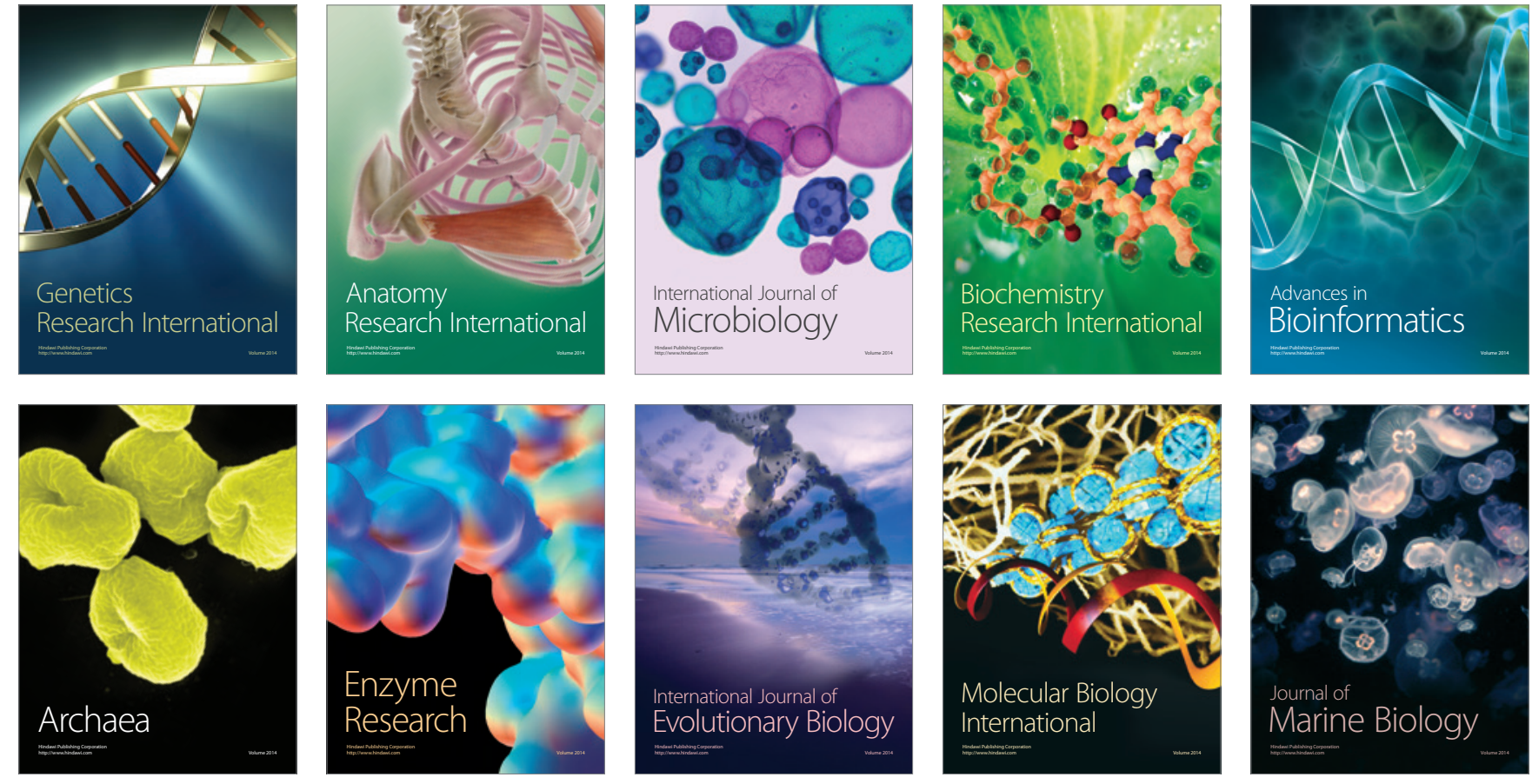